\title{
Standardizing Knowledge in a Multicultural Society
}

\author{
CHRISTINE SLEETER \\ California State University Monterey Bay \\ Seaside, California, USA
}

JAMY STILLMAN

University of California, Los Angeles

Los Angeles, California, USA

\begin{abstract}
Across the United States, in an attempt to raise standards for student learning, states have developed curriculum standards that specify what students are to learn. Raising standards has become synonymous with standardizing curriculum. This study critically examines the reading/language arts and history-social science standards documents in California to explore how the standards movement has reconfigured codes of power, and in whose interests. To address this question, we used Bernstein's (1975) theory of codes of power in curriculum. Bernstein suggested that codes of power can be uncovered by examining how curriculum is classified and framed. Our analysis suggests that the state's curriculum standards fit within a political movement to reconfigure power relations among racial, ethnic, language, and social class groupings. This is not simply about trying to improve student learning, but more important, about reasserting who has a right to define what schools are for, whose knowledge has most legitimacy, and how the next generation should think about the social order and their place within it.
\end{abstract}

\section{INTRODUCTION}

Curriculum in any time and place becomes the site of a battleground where the fight is over whose values and beliefs will achieve the legitimation and the respect that acceptance into the national discourse provides. (Kliebard, 1995, p. 250-51)

Across the United States, in an attempt to raise standards for student learning, states have developed curriculum standards that specify what students are to learn. Raising standards has become synonymous with standardizing curriculum. This study critically examines two sets of current

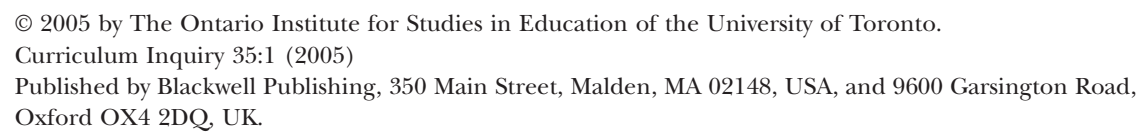


curriculum standards document in California. There, very detailed curriculum standards were developed during the 1990s in history-social science, reading/language arts, mathematics, natural science, and visual and performing arts. In 2001, state legislation created a seamless web specifying not only subject matter content in every discipline for $\mathrm{K}-12$, but also disciplinary subject matter university coursework for teacher preparation. Standards for teacher credentialing were also aligned to K-12 content standards, making the main role of teacher education preparation to teach state-adopted curriculum. The purpose of this article is to examine standards in two disciplines in order to explore their connection with broader power relationships.

\section{THEORETICAL FRAMEWORK}

For over a century, curriculum in the United States has periodically surfaced as a lightening rod for debate about what schools should do, and more broadly, about basic values and beliefs about how young people should view society, and what adults expect of them as they enter the adult world. Like Kliebard (1995), Bernstein and Solomon (1999) argued that in any society, groups struggle for the means to control consciousness of people, and that education develops the consciousness of children and youth: "The pedagogic device, the condition for the materializing of symbolic control, is the object of a struggle for domination, for the group who appropriates the device has access to a ruler and distributor of consciousness, identity, and desire" (p. 268).

To examine the legitimation of power and control in two disciplines in California, we used Bernstein's (1975) theory of codes of power in curriculum. Bernstein suggested that codes of power can be uncovered by examining how curriculum is classified and framed. Classification refers to the degree to which curriculum contents are separated and bounded-for example, the strength of boundaries among disciplines, or between school knowledge and everyday knowledge. "Where classification is strong, contents are well insulated from each other by strong boundaries" (p. 88). Bernstein distinguished between two basic types of curriculum in relationship to classification: a collection code curriculum, and an integrated code curriculum. A collection code reflects strong classification; the stronger the classification, the more hierarchical the structure of knowledge, the more status academic knowledge has over everyday knowledge, and the greater degree to which teaching moves sequentially from basic facts toward the deep structure of a given discipline. An integrated code curriculum is weakly classified, boundaries are blurred, and knowledge is viewed much less hierarchically. Curriculum tends to be organized around themes and emphasizes the knowledge construction process rather than accumu- 
lation of disciplinary facts and concepts. Bernstein suggested that movements away from collection to integrated code curricula may reflect broader social movements that attempt to "alter power structures and principles of control" (p. 111). Conversely, movements that attempt to reestablish collection code curricula may reflect broader movements to reestablish traditional power hierarchies.

Frame refers to "the degree of control teacher and pupil possess over the selection, organization, pacing and timing of the knowledge transmitted and received in the pedagogical relationship" (Bernstein, 1975, p. 89). Under strong framing, teachers and students learn to work within a set of received knowledge; under weak framing, they are encouraged to use their own sense-making process. Curriculum that has strong framing offers little decision-making power to teachers or students; curriculum that has weak framing encourages classroom decision-making. "Framing regulates the form of socialization into the category system, that is, into the positional structure, and into the form of the power relationships which constitute, maintain and reproduce the structure" (p. 179). In other words, teachers and students learn their place in hierarchical power relationships through the degree of power they have over selecting, organizing, and teaching or learning curriculum.

These codes are constructed and play out within structural relationships, which include relationships among teachers (grade level, subject area), between teachers and administrators, and among students (particularly how students are grouped in school). Ultimately, Bernstein was interested in how young people are inducted into a stratified and segmented society. Because he viewed education as a primary regulator of society, he saw classification and framing as tools for examining how regulation is imposed and, at times, disrupted.

The standards movement in the United States followed a period in which power relations in the broader society had been disrupted. The civil rights movement had spawned various movements to redistribute power, which in education took forms such as school desegregation, multicultural education, and bilingual education. To what extent can the standards movement be understood as an attempt to restore earlier power relations? Bernstein's framework enables us to examine this question as it is reflected in curriculum documents. Below, we develop and situate the standards movement in a historic context, then report our analysis of a set of content standards documents.

\section{From Civil Rights to Standardization}

Beginning with the civil rights movement in the 1960s, the ethnic studies movement, the women's movement, and other democratically based 
equity movements challenged collection code curricula that had defined academic knowledge of Europeans and European Americans as superior to other knowledge systems. When schools were initially desegregated, parents and community leaders of color began to demand that the curriculum reflect their communities, and that teachers expect the same level of academic learning of their children as they did of white children (Gay, 1995; Weinberg, 1977). Historically disenfranchised communities argued that textbooks and other sources of curriculum were too often culturally irrelevant to students of color, and inaccessible to students of non-English language backgrounds. Particularly on college campuses, youth demanded ethnic studies courses that related to their own experiences. Ethnic studies and women's studies scholarship burgeoned; faculty hired to teach such courses found themselves needing to unearth subjugated knowledge to construct new curricula (Gay).

By the 1980s, models and approaches to multicultural and bilingual curriculum had been created; they tended to follow integrated curriculum codes and weakened framing in that many of the models emphasized teachers' and students' power over the knowledge construction process. For example, Watkins's (1993) six black curriculum frameworks and Tetreault's (1989) phases of the integration of women into curriculum dislodged classifications within traditional academic knowledge. Ladson-Billings's (1994) and Gay's (1995) research on culturally relevant pedagogy, along with bilingual education research, demonstrated how essential it is for all students, and especially second-language learners, to build their academic skills on everyday life experiences and family-based knowledge (e.g., Cummins, 1996; Gutierrez et al., 2002; Ruíz, 1995; Tharp et al., 2000). Bilingual education research demonstrated that primary language literacy among English learners supports second language acquisition, and that fluency in multiple languages is superior to fluency in only one (e.g., Cummins, 1996; Dicker, 1996; Hakuta, 1986; Thomas \& Collier, 1999).

More general conceptions of language learning and language arts instruction also shifted. In particular, more holistic and integrated approaches to reading and writing instruction emerged and began to challenge traditional pedagogical models of language arts instruction (Emig, 1971, 1982; Goodman \& Goodman, 1979; Graves, 1982; Gutierrez, 2001). Scholarship that argued for a more social and cultural notion of language learning followed (e.g., Heath, 1983), and influenced the development of and research about language arts instructional models that showed effectiveness for culturally and linguistically diverse children. In particular, researchers came to considerable consensus about the most helpful instructional principles and processes, emphasizing the importance of contextualized rather than skill-driven instruction, and the connections between language, thinking, values, culture, and identity (Center for Research on Education, Diversity and Excellence, 2002; Gibbons, 2002; Wink \& Putney, 2002). 
Social science was also a subject of debates. One view was that the main purpose of social studies is to prepare citizens. That view conflicted with the more traditional view of social science as discipline based, with curriculum drawing from discipline-specific content. Yet a third view defined social science as a process of reflective inquiry (Brophy \& VanSledright, 1997); for example, Wineberg (2001) suggested teaching students to think historically and to analyze historical texts as artifacts of human production in specific contexts, rather than delivering historian-constructed interpretations of the past.

The mid-1980s ushered in the standards movement, which viewed the main purpose of schooling as bolstering the U.S. economy and its national sovereignty and security (Coles, 2000; Engels, 2000). Its genesis is often traced to the publication of $A$ Nation at Risk in 1983 (National Commission on Excellence in Education). Subsequent reform reports expressed concerns of the business community: that technological advances and global restructuring were transforming the nature of production and work, and that the United States would need to develop many, many more workers for demands of this new economy. These new workers would need to master "technological visualization; abstract reasoning, mathematical, scientific, and computer expertise; knowledge of specific technologies and production techniques; individual initiative; and so forth" (Berliner \& Biddle, 1995, p. 141). On the heels of these reform reports came a barrage of highly visible conservative critiques of multiculturalism and bilingual education (e.g., Bloom, 1989; Ravitch, 1990; Schlesinger, 1992), which targeted curricular changes and policies that had been instituted in schools and universities. They charged that multiculturalism was damaging education and social cohesion, and that multicultural and bilingual curricula were intellectually weak, addressing minority student achievement in damaging ways by appealing mainly to self-esteem rather than hard work and intellectual challenge.

The reform reports and the conservative critiques of multiculturalism depicted schools, and U.S. society generally, as being in a state of crisis. In response, beginning in the 1980 s, states began to construct disciplinary content standards. By the mid-1990s, most states had content standards in place and were designing or beginning to implement statewide systems of testing based on them. No Child Left Behind, passed by Congress and signed into law in 2001, mandates that states receiving federal funding implement accountability systems, with annual testing in reading and math.

The specificity, user-friendliness, and prescriptiveness of content standards vary from state to state. In some states, they are highly detailed and specific, leaving fairly little room for local decision-making, while in others, they are very broad and general. For example, in their analysis of 14 states' language arts standards documents, Wixson and Dutro (1999) compared the structure of standards in Texas and California, both of which serve 
diverse students. While California's language arts standards comprise three volumes, only one of which explicitly addresses how to teach English language learners (ELLs), Texas includes both standards and instructional guidelines in one accessible and user-friendly document that integrates strategies throughout for tailoring instruction to ELLs.

Within the standards movement, the general paradigm shifted from integrated code curricula to collection code curricula, and from weak framing to strong framing, using science to justify certain pedagogies. State and federal governments define science to mean studies that claim to be value-neutral and rely heavily on quantitative methods. Reading and language arts particularly were affected by the seminal "scientific" study supporting phonics instruction, commonly called The Foorman Study (Foorman et al., 1998) and sponsored by the National Institute of Child Health and Human Development (NICHD). ${ }^{1}$ Across the country, "alignment" has become a watchword as schools and school districts have worked to align their curriculum with state standards and state testing.

\section{Standardizing Curriculum in California}

California has a highly diverse student population. In academic year 2002-2003, students in California public schools were 45\% Hispanic, 34\% non-Hispanic White, 8\% Black, 8\% Asian, 3\% Filipino, 1\% American Indian/Alaskan Native, and 1\% Pacific Islander (Educational Demographics Office, 2004). Over $25 \%$ of the students came to school speaking a first language other than English. One out of every four students was an ELL, and one in three elementary school students was considered to have limited English proficiency (Gándara et al., 2003).

California is often cited as having led the nation's standards movement by drafting curriculum frameworks in the early 1980s, which became the cornerstone of its standards-based reform program. For all content areas, the State Board of Education, appointed by the governor, makes curriculum decisions. Subject-matter decisions are made by committees that report to the Curriculum Commission. Members of the Curriculum Commission are appointed by the State Board of Education, the governor, and the Speaker of the House of the Assembly. Commission recommendations go to the State Board of Education, which then flow down to the colleges and the counties, then to districts, then to schools. In other words, the decision-making structure is decidedly top-down.

Content standards guide adoption of textbooks for grades one through eight by the State Board of Education and construction of state achievement tests. The Public School Accountability Act of 1999 established a system of achievement testing based on curriculum standards, and on rewarding high-performing schools and sanctioning low-performing schools. The 2002 Master Plan for Education, which outlines recommen- 
dations for education from preschool through university, makes frequent reference throughout to aligning curriculum and teacher preparation to the state's content frameworks and standards.

Our main question, then, is this: Given the historic context of struggles over curriculum, how has the standards movement reconfigured codes of power as manifest in curriculum, and in whose interests?

\section{The Standards Documents}

We conducted a content analysis of the following California frameworks and standards.

- History-Social Science Framework and Standards for California Public Schools (California Department of Education, 2001)

- English-Language Arts Content Standards for California Public Schools (California Department of Education, 1997)

- Reading/Language Arts Framework for California Public Schools (California Department of Education, 1999b)

- English Language Development Standards (California Department of Education, 1999a)

Content standards in both disciplines were initially adopted in 1987. The History-Social Science Framework and Standards document, which was readopted three times with only minor updates, describes what should be taught in the social studies curriculum in considerable detail for every grade except ninth. (For ninth grade, there are suggested units, but local decision-making over curriculum is allowed.) Its initial adoption was highly controversial and was contested vigorously by numerous educators, community groups, and scholars, particularly African American scholars. The main objection was that it had been written primarily by European American scholars working within a European American perspective that conceptualizes everyone within an immigrant paradigm. In so doing, it ignores perspectives that arise from nonimmigrant historical experiences, such as those of Native Americans and African Americans (see Cornbleth \& Waugh, 1995; King, 1992). These concerns were never addressed. In fact, the preface to the newest edition says that "a consensus existed in the field for the framework" (p. viii). Ultimately, several school districts (notably San Francisco, Oakland, and Hayward) rejected the adopted texts or recommended that they be used only with substantial alternatives.

In 1997, California adopted a new set of reading/language arts standards and frameworks to replace those adopted in 1987. These new documents embody a distinctly different theoretical orientation from those issued previously by shifting away from a constructivist, literature-based approach to reading instruction to a direct instruction approach. This shift 
is evident throughout all three of the reading/language arts documents that we analyzed, mainly in the authors' tendencies to make theoretical claims reminiscent of the previous framework, and then to offer content standards and practical guidelines from the direct instruction approach.

Introductions to the documents in both disciplines address California's diverse students, especially the increasing number of students who are not proficient in English. The authors make clear their dedication to the academic success of such students and their perception that the content frameworks and standards are based upon consensus about what California's students need to know. What does an analysis of how curriculum is classified and framed reveal?

\section{METHODOLOGY}

We used two main processes to analyze these documents. First, we read them for themes, keeping systematic notes on each theme. For the reading/language arts documents, we read for themes reflecting a sociocultural perspective (operationalized through terms such as contextualization, scaffolding, primary language instruction, bilingual, and bicultural) and a skill-based perspective (operationalized through terms such as decode, phonics, phonemic awareness, and phoneme). For the history-social science document, we read for themes reflecting multicultural content (such as depiction of African American history, depiction of women, depiction of European immigration) and pedagogical approaches (such as interdisciplinarity, use of student-generated historical analysis, use of expert-generated historical analysis).

Second, we counted words and items in each document that reflected patterns related to our thematic analysis. We counted the demographic characteristics of people named for study in the history-social science document, but not the reading/language arts documents, which did not name people for study. There, we counted terms representing pedagogical approaches, and references to ELLs.

\section{RESULTS OF ANALYSIS}

Below, we describe how curriculum is classified and framed, according to Bernstein's analytical framework.

\section{Classification}

Our analysis of classification addresses how knowledge boundaries and hierarchies are established. The boundaries we identified include those 
between disciplines and languages. We also noted distinct patterns in sequencing and structuring knowledge in each discipline.

The standards solidify disciplinary boundaries. Separate disciplinary committees prepared the standards, and even though the covers of the documents are similar, their overall internal structure is not. The Englishlanguage arts standards for every grade level are organized into four areas: reading, writing, written, and oral English language conventions, and listening and speaking. Standards and substandards are then organized into each of these four areas. In history-social science, the standards and substandards are organized mainly according to theme, time period, and geographic location, which differ from one grade level to the next. For example, second grade is organized around the theme of "people who make a difference"; it includes five standards that have up to four substandards. Eighth grade is organized chronologically around U.S. history; 12 standards each have between three and nine substandards. That each discipline's standards are organized according to a different internal logic would tend to discourage constructing interdisciplinary curriculum.

The English-Language Arts Content Standards (ELA) mandates what all students must learn. The Reading/Language Arts Framework details how and in what order teachers must introduce language arts material. These two documents separate what students must learn from pedagogy and instructional decision-making.

The three reading/language arts documents solidify language boundaries and the primacy of English. The English Language Development Standards (ELD) are mapped against the English-Language Arts Content Standards to help California's ELLs to “ 'catch up' to the state's monolingual English speakers” (California Department of Education, 1997, p. 1). The ELA standards are named 130 times as the instructional objectives of the ELD standards. Learning in English is given clear primacy over learning reading, writing, and other language arts skills in any other language. The documents ignore language arts proficiencies that students might have in a language other than English. For example, while the introduction to the ELD standards document acknowledges research supporting the value of primary language literacy, the standards themselves encourage teachers to tap students' primary language knowledge only with reference to students' familiarity with English phonemes.

The standards set up a complex structure of knowledge for each discipline. In both, knowledge derived from students' experience is subordinated to school knowledge. For example, the ELA standards refer to students' familiar experiences and interests primarily with reference to their selection of topics in which to practice oral presentation. Otherwise, there is little reference to students' interests and experiences. The historysocial science standards refer to students' community and local area in the primary grades, but from fourth grade onward, detail content to learn without reference to students' lived experiences. In the remainder of this 
section, we examine how disciplinary knowledge is constructed within each of the two disciplines.

Language arts is hierarchically structured into a learning sequence, leading toward classification of students based on mastery of that sequence. Students are to learn skills first, and build meaning on skills. This emphasis on sequence is premised on the assumption that "a comprehensive program ensures that students master foundational skills as a gateway to using all forms of language as tools for thinking, learning and communicating" (California Department of Education, 1999b, p. 4). The authors emphasize their commitment to a balanced literacy program, but also state that "balanced does not mean that all skills and standards receive equal emphasis at a given point in time. Rather, it implies that the overall emphasis accorded to a skill or standard is determined by its priority or importance relative to students' language and literacy levels and needs" (p. 4). Further, the standards embrace balance mainly when addressing the learning needs of native English speakers. They relegate students who are still learning English to a "back-to-basics" program until they master foundational skills.

This is not to preclude a well-trained teacher from delivering highquality reading/language arts instruction to ELLs. Nonetheless, following the standards' sequencing with fidelity may lead teachers who have received little or no training in this area to a very imbalanced program, particularly for ELLs. The Reading/Language Arts Framework contends that "simplified texts should be used only with students with weak proficiency in English," and that "students who use the simplified text need intensive English language instruction to enable them to catch up with their peers" (California Department of Education, 1999b, p. 76). In other words, California's reading/language arts standards enable balanced instruction more for students who read English at or above grade level than for others.

All three reading/language arts documents are heavily weighted toward phonics instruction and construct literacy largely as word analysis, particularly in the early grades. The words "phonemes," "phonics," and "phonemic awareness" are mentioned 200 times in these documents collectively. They are mentioned only 22 times in the 84-page ELA document (14 of which are in the glossary), but 66 times in the 93-page ELD document (only two of which are in the glossary). Further, the ELD standards emphasize it from kindergarten through the $12^{\text {th }}$ grade, while in the ELA standards, most references to phonics-driven instruction appropriately diminish after the fourth grade. Thus, the ELD standards treat phonics mastery as a gatekeeper for English learners through the $12^{\text {th }}$ grade.

As a result, language minority students may be precluded from engaging in literary analysis and other intellectual activities that would prepare them for admission to higher education institutions. And although the standards at times suggest to teachers that optimal student learning happens when skill instruction is embedded in authentic texts, discrete skill 
instruction is consistently separated from comprehension or literary analysis by requiring that activities such as literature-based instruction be introduced only after students demonstrate their discrete skill mastery.

Literature is further separated from skills instruction by being developed in yet a fourth document. Each time the authors of the reading/ language arts documents suggest using literature, they advise teachers to refer to the state-sponsored list, Recommended Literature: Kindergarten Through Grade Twelve (California Department of Education, 1996). None of the titles is integrated into the standards documents.

The History-Social Science Framework and Standards document gives clear primacy to history as "a story well told" (California Department of Education, 2001, p. 4). The story around which the standards are structured develops over about 10 grade levels. Its central idea is that, as an immigrant society, the United States has always been multicultural; students need to "understand the special role of the United States in world history as a nation of immigrants" (p. 21). At the same time, "its institutions were founded on the Judeo-Christian heritage, the ideals of the Enlightenment, and English traditions of self-government" (p. 64). Its unfinished story tells "the historic struggle to extend to all Americans the constitutional guarantees of equality and freedom" (p. 21). Much of its content revolves around the political system of the United States as outlined in the Constitution, and is developed primarily through the conceptual tools of chronology and geography, as its introduction states.

The dominant storyline revolves around European and European Americans, particularly men. For example, we counted representation of people. Of the 96 Americans named for study, 82\% were male and $18 \%$ were female. They were $77 \%$ white, $18 \%$ African American, $4 \%$ Native American, 1\% Latino, and 0\% Asian American. Authors of the historysocial science framework recommend integrating children's literature with history (a break in the otherwise strong classification system) and gave specific suggestions. We tallied the racial and gender composition of the 88 authors of recommended children's literature. Fifty-seven percent were male, and $35 \%$ were female; we were unable to identify the gender of $8 \%$. Sixty-two percent were European or European American, 19\% were African or African American, 1\% (one author) was Native American, 7\% were Asian or Asian American, and none was Latino or South American; we were unable to identify the background of $10 \%$. We saw a noticeable effort to include stories about diverse European ethnic groups, including Swedish, Irish, and Russian immigrants.

Because history-social science was constructed mainly as a story of immigration, stories of conquest were filtered through that paradigm using the tools of timelines and maps. Students first study European colonialism briefly in fourth grade in the context of California history. In fifth grade, they meet European explorers largely through map study, and then they study English settlements in North America. In seventh grade, they 
examine different world regions, concluding with a unit on "the Age of Exploration to the Enlightenment." European exploration and conquest are mentioned, but political ideals of the Enlightenment receive at least as much attention. This is important because it casts colonialism not as the taking of land, life, and sovereignty, but rather as the spread of reason, ideas, and liberty. In eighth grade, students encounter "the extension of the United States beyond its borders" (California Department of Education, 2001, p. 106), but relationships between the United States and Puerto Rico, the Philippines, or islands in the Pacific and Caribbean are not mentioned. In tenth grade, there is some review of "the worldwide expansion that was fueled by the industrial nations' demand for natural resources and markets and by their nationalist aspirations," presented as map study in which students survey colonial possessions of several European nations and the United States (California Department of Education, 2001, p. 126). Thus, it is possible to graduate from high school with only a fuzzy idea of European and United States histories of conquest and exploitation.

The conquests of northern Mexico and indigenous peoples are marginalized and sanitized. In third grade, students briefly study indigenous people of the past, then move on. In fourth grade, when studying the history of California, they briefly study American Indian nations in California's past. In fifth grade, students begin to study U.S. history, starting with a unit devoted to pre-Columbian indigenous people. After that unit, indigenous people appear only sporadically, and in relationship to the story of the westward movement of European Americans. Students study the conquest of Mexico in fourth, fifth, and eighth grades, but do so mainly as map study and timelines. Given that California used to be part of Mexico, and became a part of the United States through conquest, this casting of history negates family knowledge of many students of Mexican and indigenous descent.

To summarize, the documents set up strong classification, solidifying a collection code. With the exception of the history-social science framework's recommendation to connect history with children's literature, the disciplines are treated as distinctly separate, each having its own internal and hierarchical structure of knowledge. Reading/language arts is conceptualized as an accretion of skills acquired sequentially and in English. As a result, ELLs may well have less access to higher-order thinking than native English speakers, because thinking and literary analysis in a student's first language do not count. History-social science is constructed as a detailed story, sequenced over several grade levels, and organized around historically dominant groups' perspectives, experiences, and ways of seeing the world. The high degree of detail in both disciplines and the differing organizational systems that structure them would discourage interdisciplinary teaching or development of other integrated code curricula. Further, the privileging of English and use of English proficiency as a gatekeeper and the privileging of a European American immigration story as the back- 
bone for academic content in the social sciences establish knowledge of white English speakers as dominant.

\section{Framing}

Framing refers to the degree to which teachers and students have authority to bring their own questions, points of view, organization, and pacing to the curriculum. We found reading/language arts to be more strongly framed than history-social science.

Compliance with the standards is enforced mainly through testing and textbooks. This alignment is more direct in reading/language arts than in history-social science. Each year, all public school students in grades 2-11 are required by state law to take standardized tests, which focus heavily on reading. For grades $\mathrm{K}-3$, schools can choose between only two reading series, both of which are heavily skills based and scripted. Teachers at higher grade levels have a little more choice; for example, fourth-grade teachers can select from six reading texts, and eighth-grade teachers can select from among eight texts.

Although some of California's few remaining bilingual education programs are permitted to administer standardized tests in languages other than English, these tests merely supplement English standardized tests and are not used, as the English tests are, to determine class placement, grade promotion, or a school's ranking on the scale used to determine a school's funding and state intervention efforts. Because California's Public School Accountability Act uses English tests as the only outcome measures in its school ranking system, it is increasingly difficult for teachers to stray from the reading/language arts standards even if their own professional experience leads them to believe that doing so would benefit their students.

Compliance with the history-social science content standards is enforced at the elementary level mainly through the state's textbook adoption process. Elementary students are not yet tested on mastery of this content. However, at grades 8, 10, and 11, social studies is part of the state's standardized testing program; the eighth-grade test is designed to cover the curriculum for grades six through eight. Secondary teachers have more latitude than elementary teachers to choose texts, but are held accountable through student testing.

Both disciplines are strongly framed through the degree to which content and skills are minutely specified, and through use of disciplinary expertise and science to support the standards. The reading/language arts documents mask ideological debates about literacy by using rhetoric of science. For example, the introduction to the Reading/Language Arts Framework document states, "reading/language arts and related disciplines are the beneficiaries of an abundance of converging research that produces a professional knowledge base related to fostering and sustaining compe- 
tence in the language arts, particularly beginning reading" (California Department of Education, 1999b, p. 3). The authors name a study sponsored by the National Research Council (1998) as "most important" because of its claim that "there is [now] a convergence of evidence to guide instruction in the language arts" (p. 3). All three documents rely heavily on this research to substantiate their emphasis on phonics instruction and phonemic awareness, but there is a notable absence of references to studies that support alternative approaches to reading instruction, particularly sociocultural approaches that may be more effective than phonics-driven methods, especially for diverse students.

We examined the documents for the extent to which they frame how teaching is to occur, particularly given the diverse students teachers have. Content in reading/language arts is highly prescribed. At several points in the ELD and ELA documents, the authors mention the "special needs" of ELLs and suggest that teachers modify their instruction to better meet them. Paradoxically, neither document suggests how to do this. In fact, neither document mentions the terms "scaffold," "specially designed academic instruction in English (SDAIE)," or "contextualize," all of which are commonly used in literature that details effective ways of teaching secondlanguage acquisition.

The Reading/Language Arts Framework, on the other hand, mentions the word "scaffold" many times in the section entitled "Universal Access." This section, featured throughout the document, is broken down into three subsections in an effort to address the needs of (1) students with reading difficulties or disabilities, (2) ELLs, and (3) advanced learners. A universal access section is offered at each of the early grade levels, but it is included less frequently at the higher grades. At each grade level, only a few standards are mentioned and discussed in detail; teachers are then given suggestions for adapting the standards to meet their students' needs. For example, project extension guidelines are offered for advanced learners, and scaffolding interventions are offered for English learners. To the extent that the universal access section suggests that teachers tailor their instruction to their students, it could be seen as weakening the framing of curriculum by inviting teacher judgment. At the same time, we found the 300-plus-page Reading/Language Arts Framework so unwieldy, it was difficult to imagine a teacher finding the time or wherewithal to study these suggestions. Overall, the three reading documents language arts taken together specify so many skills (English-Language Arts Content Standards for California Public Schools, Reading/Language Arts Framework for California Public Schools, and English Language Development Standards) to teach and the order in which they are to be introduced, that one could see drill on the standards as the best way to get through everything.

In addition, the universal access section of the Reading/Language Arts Framework emphasizes using students' scores ("standard deviations") on the language arts portion of the state's standardized test to "diagnose" students' gaps in learning. Accordingly, teachers are then urged to integrate 
test preparation into their intervention efforts (California Department of Education, 1999b, pp. 226-29). Closely tying the standards documents to standardized tests raises questions about the degree to which teachers have the latitude to implement the standards as they deem most effective, particularly for special needs students such as ELLs and learning disabled students.

The language arts' emphasis on sequencing similarly strengthens the framing of the language arts curriculum, particularly for English learners and their teachers. For example, the Reading/Language Arts Framework suggests that when students demonstrate persistent difficulty in mastering the language arts standards for their grade level, teachers should be "differentiating curriculum and instruction, using grouping strategies effectively, and implementing other strategies" in order to meet the needs of these students (California Department of Education, 1999b, p. 226). In principle, this would allow for a weaker framing of the curriculum by affording teachers the chance to exercise their own professional judgment about instructional delivery. Yet, the Framework also encourages teachers to deliver instruction for special needs students that is even more sequential than for other students (p. 229). This sequential format, which reads like a list of skills and instructional activities, would most easily be aligned with a scripted skill-driven program, leaving little room for modification.

The History-Social Science Framework and Standards encourages higherorder thinking and active teaching processes throughout the grade levels. The document acknowledges that historians construct history, and that students should become aware of debates among them. For instance, a standard for 11th grade requires that students "evaluate major debates among historians concerning alternative interpretations of the past" (California Department of Education, 2001, p. 142). And occasionally the History-Social Science Framework mentions how historians work and that they often disagree with each other. But the main learning process that the History-Social Science Framework authorizes is consumption of an interpretation of the past prepared by someone else, rather than learning to construct an interpretation using the tools of historical thinking. The standards are largely content driven, spelling out conclusions that students should reach. For example, the term "analyze" is used repeatedly to describe what students should do: "At the same time students should analyze periodic waves of hostility toward newcomers and recognize that the nation has in different eras restricted immigration on the basis of racial, ethnic, or cultural grounds." (p. 10). But the authors have already constructed a general analysis for students; their task is to comprehend analysis rather than learn to construct an original analysis based on historic data. The authors recommend using a variety of teaching strategies such as debates, simulations, role-play, narratives, and video so that students will become engaged in learning the material. It is possible for teachers to alter how they construct their history or social studies curriculum, but because the curriculum as a whole is packed, it is simply easier for teachers to follow what they are given. 
California's new teacher credential standards also strengthen the framing of the curriculum. As discussed elsewhere (Sleeter, 2003), the teacher credential standards explicitly define teacher education as preparation to deliver the state's academic content standards. The phrase "stateadopted academic content standards" appears 34 times in California's new Professional Teacher Preparation document, and 26 times in its Professional Teacher Induction Program document. By contrast, the phrases "culturally relevant, "multicultural," and "justice" appear in neither one. Disciplinary content preparation for teachers is also tied to the content standards; disciplinary programs must be approved by the state as being aligned to the content standards for certification programs to be authorized. In this way, what teachers learn in the university should match with what is in the standards, lessening the possibility that teachers will bring to the classroom ideas that conflict.

To summarize, the state standards strongly frame curriculum in both reading/language arts and history-social science. In the reading/language arts documents, the emphasis on sequence, the prescriptive nature, and the strict compliance enforced by high-stakes standardized testing ensures that a back-to-basics reading/language arts curriculum will be implemented across the state, and will be the most strictly enforced with special needs children. In addition, the dearth of instructional strategies for teachers of English learners and the inaccessibility of guidelines that are included discourage straying from or expanding upon the curriculum, even in the interest of meeting the needs of individual students. Further, because of the theoretical contradictions present throughout all three reading/language arts documents, a teacher may be given the impression that he or she can implement a literature-based and linguistically responsive reading/language arts program, but then be limited from doing so simply because of a lack of available instructional time, and/or state and district pressure to "teach to the test." The History-Social Science Framework and Standards are content driven, although filled with suggestions for student activities. Teachers have more latitude for deciding how to teach history and social studies than reading, but the curriculum is so packed and backed up by state-adopted texts that it is an effort to not follow the standards.

\section{DISCUSSION AND IMPLICATIONS}

Given the context of California and the historic context of struggles over curriculum, how has the content standards movement reconfigured codes of power, and in whose interests?

Our analysis of the way that the standards classify curriculum shows that they reassert disciplinary boundaries and boundaries between traditional academic knowledge in English versus knowledge in languages other than 
English, as well as knowledge from home and community. In both reading/ language arts and history-social science, the content standards specify a structure of knowledge and sequence for teaching it. In reading/language arts, the structure builds higher-order thinking on discrete skills, and in so doing, makes higher-order thinking more accessible to English-speaking students with average or above average reading skills than to everyone else. Further, the reading/language arts documents consistently refer to California's nonwhite, non-English speaking students as "these students" and "they" instead of one of "us." History-social science is structured largely as a story of European immigration and the construction of a nation around Judeo-Christian values and European political institutions. Implicitly, in an attempt to reduce the significance of the growing demographic diversity of California' students, the content standards set up a we/they perspective in which "we" are of European, Judeo-Christian heritage and English-speaking, and "they" are not. Ideologically, the curriculum in both disciplines rests most comfortably on historically dominant groups' perspectives, language, and ways of seeing the world.

Framing examines the place that teachers and students are expected to take within this structure, and the degree of latitude they have for defining that place. Our analysis of the standards shows that, particularly in reading/language arts, teachers and students are expected to follow the state's prescription. Compliance is enforced mainly through statewide standardized testing in English, and through the textbook adoption process. Compliance is also enforced through the sheer prescriptiveness of a packed curriculum, particularly at the elementary level. Further, compliance in the way that reading/language arts is taught is to be enforced mainly in schools that score low on standardized tests, and with students designated as having special needs.

Although the content standards in both disciplines rest within a specific ideology, they are presented as if there were no serious ideological debates to consider. Both present a detailed curriculum outline, and both give enough verbal recognition to cultural, racial, and linguistic diversity that teachers without a deep understanding of diverse intellectual funds of knowledge, diverse ideological perspectives, and effective pedagogy for diverse students might see the standards as fully inclusive. The use of disciplinary "experts" as curriculum document writers and the use of "scientific" research about reading encourage compliance. Although the documents occasionally suggest use of project- and literature-based teaching, the prescriptiveness of the standards, limited availability of instructional time, and adoption of a mandatory scripted reading program steer teachers toward a back-to-basics curriculum. In the top-down curriculummaking structure of California, teachers and students have little recognized power.

This standards-based curriculum planning process hearkens back to that described by Cubberley almost a century ago, when he characterized 
schools as "factories in which the raw products (children) are to be shaped and fashioned into products to meet the various demands of life" (cited in Beyer \& Liston, 1996, p. 19). Like a century ago, curriculum is being organized scientifically for efficiency, deriving learning objectives from social and economic needs and casting teachers as managers of the process of producing student achievement scores. But both sets of standards, and particularly those in reading/language arts, deflect attention from their ideological underpinnings by virtue of being situated within a testing movement. Rather than asking whose knowledge, language, and points of view are most worth teaching children, teachers and administrators are pressed to ask how well children are scoring on standardized measures of achievement.

Our analysis suggests that California's curriculum standards fit within a political movement to reconfigure power relations among racial, ethnic, language, and social class groupings. This is not simply about trying to improve student learning, but more important, about reasserting who has a right to define what schools are for, whose knowledge has most legitimacy, and how the next generation should think about the social order and their place within it.

\section{NOTES}

1. This use of science may explain why the current standards go largely unquestioned (Shannon, 2001). A growing body of research is beginning to demonstrate that The Foorman Study was flawed and even deliberately manipulated to attain particular results (Coles, 2000; Taylor, 1998), and that subsequent advocacy of phonological reading strategies has been overstated (Swanson et al., 2003).

\section{REFERENGES}

Berliner, D. C., and B. J. Biddle. 1995. The manufactured crisis. Cambridge, MA: Perseus Books.

Bernstein, B. 1975. Class, codes and control. Rev. ed. London: Routledge and Kegan Paul.

Bernstein, B., and J. Solomon. 1999. Pedagogy, identity, and the construction of a theory of symbolic control: Basil Bernstein questioned by Joseph Solomon. British Journal of Sociology of Education 20 (2): 265-80.

Beyer, L., and D. Liston. 1996. Curriculum in conflict. New York: Teachers College Press.

Bloom, A. C. 1989. The closing of the American mind. New York: Simon \& Schuster.

Brophy, J., and B. VanSledright. 1997. Teaching and learning history in elementary schools. New York: Teachers College Press.

California Department of Education. 1996. Recommended literature: Kindergarten through grade twelve. Sacramento, CA: Author. Available at http://www.cde.ca.gov/ci/literature. 
1997. English-language arts content standards for California public schools. Sacramento, CA: Author.

. 1999a. English language development standards. Sacramento, CA: Author.

- 1999b. Reading/language arts framework for California public schools. Sacramento, CA: Author.

- 2001. History-social science framework and standards for California public schools. Sacramento, CA: Author.

Center for Research on Education, Diversity, and Excellence. 2002. Research evidence: Five standards for effective pedagogy and student outcomes. Technical Report No. G1, March 2002. University of California, Santa Cruz. Available at http://crede.ucsc.edu/pdf/evidence_gl.pdf.

Coles, G. 2000. Misreading reading: The bad science that hurts children. Portsmouth, NH: Heinemann.

Cornbleth, C., and D. Waugh. 1995. The great speckled bird: Multicultural politics and education decision-making. New York: St. Martin's Press.

Cummins, J. 1996. Negotiating identities: Education for empowerment in a diverse society. Ontario, CA: California Association for Bilingual Education.

Dicker, S. 1996. Languages in America: A pluralist view. Clevedon, UK: Multilingual Matters.

Educational Demographics Office. 2004. Enrollment in California public schools by ethnic designation, 1981-82 through 2002-03. Sacramento: California Department of Education. Available at http://goldmine.cde.ca.gov/demographics/reports/ index.html.

Emig, J. 1971. The composing process of twelfth graders. NCTE Research Report No. 13. Urbana, IL: National Council of Teachers of English.

33: $64-75$.

Engels, M. 2000. The struggle for the control of public education: Market ideology vs. democratic values. Philadelphia: Temple University Press.

Foorman, B. R., D. J. Francis, J. M. Fletcher, and C. Scatschneider. 1998. The role of instruction in learning to read: Preventing reading failure in at-risk children. Journal of Educational Psychology 90: 37-55.

Gándara, P., R. Rumberger, J. Maxwell-Jolly, and R. Callahan. 2003. English learners in California schools: Unequal resources, unequal outcomes. Education Policy Analysis Archives 11, no. 36. Available at http://epaa.asu.edu/epaa/v11n36/.

Gay, G. 1995. Curriculum theory and multicultural education. In Handbook of research on multicultural education, ed. J. A. Banks and C. A. M. Banks, 25-43. New York: Macmillan.

Gibbons, P. 2002. Scaffolding language, scaffolding learning: Teaching second language learners in the mainstream classroom. Portsmouth, NH: Heinemann.

Goodman, K., and Y. Goodman. 1979. Learning to read is natural. In Theory and practice of early reading, vol. 1, ed. L. Resnick and P. Weaver, 137-54. Hillsdale, NJ: Erlbaum.

Graves, D. 1982. How do writers develop? Language Arts 59 (2): 173-79.

Gutierrez, K. 2001. So what's new in the English language arts: Challenging policies and practices, ¿y que? Language Arts Journal 78 (6): 564-69.

Gutierrez, K., J. Asato, M. Swantos, and N. Gotanda. 2002. Backlash pedagogy: Language and culture and the politics of reform. The Review of Education, Pedagogy, and Cultural Studies 24 (4): 335-51.

Hakuta, K. 1986. Mirror of language: The debate on bilingualism. New York: Basic Books.

Heath, S. B. 1983. Ways with words: Language, life, and work in communities and classrooms. Cambridge, UK: Cambridge University Press. 
King, J. E. 1992. Diaspora literacy and consciousness in the struggle against miseducation in the black community. Journal of Negro Education 61 (3): 317-40.

Kliebard, H. M. 1995. The struggle for the American curriculum. $2^{\text {nd }}$ ed. New York: Routledge.

Ladson-Billings, G. 1994. The dreamkeepers. New York: Jossey-Bass.

National Commission on Excellence in Education. 1983. A nation at risk. Washington, DC: U.S. Government Printing Office.

National Research Council. 1998. Preventing reading difficulties in young children. Washington, DC: National Academy Press.

Ravitch, D. 1990. Diversity and democracy: Multicultural education in America. American Educator 14 (1): 16-20, 46-68.

Ruiz, N. T. 1995. The social construction of ability and disability: Optimal and at-risk lessons in a bilingual special education classroom. Journal of Learning Disabilities 28: 491-502.

Schlesinger, A. M., Jr. 1992. The disuniting of America. New York: Norton.

Shannon, P. 2001. What's my name? A politics of literacy in the latter half of the $20^{\text {th }}$ century in America. In Becoming political, too: New readings and writings on the politics of literacy education, ed. P. Shannon, 112-41. Portsmouth, NH: Heinemann.

Sleeter, C. E. 2003. Reform and control: An analysis of SB 2042. Teacher Education Quarterly 30(1): 19-30.

Taylor, D. 1998. Beginning to read and the spin doctors of science: The political campaign to change America's mind about how children learn to read. Urbana, IL: National Council of Teachers of English.

Tetreault, M. K. T. 1989. Integrating content about women and gender into the curriculum. In Multicultural education: Issues and perspectives, ed. J. A. Banks and C. A. M. Banks, 124-44. Boston: Allyn \& Bacon.

Tharp, R., P. Estrada, S. S. Dalton, and L. A. Yamauchi. 2000. Teaching transformed: Achieving excellence, fairness, inclusion and harmony. Boulder, CO: Westview Press.

Thomas, W., and V. Collier. 1999. School effectiveness for language minority students. Washington, DC: National Clearinghouse for Bilingual Education, George Washington University.

Watkins, W. H. 1993. Black curriculum orientations: A preliminary inquiry. Harvard Educational Review 65 (3): 321-38.

Weinberg, M. 1977. A chance to learn: The history of race and education in the United States. Cambridge, UK: Cambridge University Press.

Wineberg, S. 2001. Historical thinking and other unnatural Acts. Philadelphia: Temple University Press.

Wink, J., and L. Putney. 2002. A vision of Vygotsky. Boston: Allyn \& Bacon.

Wixson, K. K., and E. Dutro. 1999. Standards for primary-grade reading: An analysis of state frameworks. The Elementary School Journal 100 (2): 89-100. 
Copyright of Curriculum Inquiry is the property of Blackwell Publishing Limited and its content may not be copied or emailed to multiple sites or posted to a listserv without the copyright holder's express written permission. However, users may print, download, or email articles for individual use. 